\title{
NÉMETH NIKOLETT
}

\section{JÁTÉK AZ ALSÓ TAGOZATON}

A mai felgyorsult világban az embereket rengeteg inger éri, ezért elég nehéz figyelmünket hosszú ideig fenntartani bizonyos dolgok iránt. A gyermekek érdeklődését megtartani pedagógusként szintén rengeteg munkát és kreativitást igényel. Az iskolában töltött idő meglehetősen sok, a tanulóknak tetemes mennyiségű óraszámban és széles spektrumban elhelyezkedő témákban kell helytállniuk. A sok inger miatt - ami főként a technikai sokszínűségből, a médiából és játékokból származik -, úgy gondolom, növeli a tanulási folyamatok hatékonyságát, ha ezeket az eszközöket az oktatásba is beemeljük, persze egy egészséges egyensúlyt fenntartva a hagyományos és modern módszerek között.

Tanítóként fontosnak tartom, hogy a tanulás a gyermekek számára érdekes és izgalmas legyen, illeszkedjen életkori sajátosságaikhoz is. Tudjuk, hogy a játékoknak igen jó a tanulástámogató képessége, s a játékra a gyermekeknek alapvetően szüksége is van. Rengeteg inger éri őket nap mint nap, és hatalmas mennyiségű tananyagot kell elsajátítaniuk az iskolában, amit játékok nélkül nem akkora motivációval és örömmel tanulnának meg, mint azokkal együtt. Érdekelt, hogy azon tanítók, akik a pályán vannak, hogyan értékelik a játékos tevékenységek szerepét az oktatásban.

A kutatásban először a megfelelő szakirodalmakat értelmeztem, majd történeti áttekintést végeztem, hogy lássam, hogyan alakult ki a mai szemlélet, milyen volt régen a nevelési és oktatási folyamat és az abban használt játékok szerepe. Ezután a szakirodalmakban szereplő népszerű játékcsoportosításokat vizsgáltam meg, melyek a gyakorlójátékok, szimbolikus játékok, konstruáló-, szabály- és komplex játékok. Miután megismerkedtem a csoportokkal, megnéztem, milyen játékgyűjtemények érhetők el a pedagógusok számára. Ezek közül kiválasztottam hatot, melyeket tantárgyakra bontva elemeztem: mely tantárgyakhoz milyen játékokat sorolhatunk az alsó tagozaton. Majd saját kutatásom eredményeit elemeztem.

A kutatásom célja az volt, hogy kiderüljön, milyen a játékok megítélése a tanítók szemszögéből. A kutatás fó kérdései arra irányultak, hogy az órát tekintve szerkezetileg hol, illetve tantárgyanként milyen gyakorisággal alkalmaznak játékokat a tanítók. Fontos kérdés még, hogy milyen motivációs tényezők és akadályok jelennek meg a játékok tekintetében, valamint hogy milyen funkciókkal használják a játékokat a megkérdezettek, és melyek a legjellemzőbb játékok.

A kutatást viszonylag nagy mintán szerettem volna végrehajtani, hogy minél megbízhatóbb eredményeket kapjak. Kvantitatív módszert választottam, melyhez kérdőívet készítettem online felületen, és közvetlen linkkel juttattam el a tanítóknak a közösségi médián keresztül. Kitétel volt a kitöltések szempont- 
jából, hogy tanító legyen az, aki válaszol, így felkerestem különböző nagy létszámú szakmai csoportokat a népszerű közösségi oldalon, s ebben osztottam meg a kérdőív linkjét. A kérdőívet összesen 347 fő töltötte ki, ami úgy vélem, mindenképp alkalmas arra, hogy a válaszok alapján tendenciák, mintázatok rajzolódjanak ki. A beérkezett válaszok száma jóval több, mint amire előzetesen számítottam a körülményekhez képest, ugyanis 2020. március 13-tól a kormány távoktatást rendelt el a köznevelési és felsőoktatási intézményekben, ami jelentős terhet rótt mind a tanulókra, mind a pedagógusokra. A távoktatás digitális formában haladt tovább, s ebből az okból kifolyólag attól tartottam, hogy nem lesz sok kitöltőm. Online önkitöltős kérdőívet szerkesztettem, hogy minél nagyobb mintát tudjak bevonni az elemzésbe. A kérdőív elkészítéséhez a Survio nevű online felületet választottam, ahol többféle kérdéstípusból is tudtam választani, hogy a lehető legpontosabb eredményeket kapjam. A felület könnyen kezelhető és felhasználóbarát volt.

A kérdőívben 19 kérdés szerepel, melyből az 1-4. kérdés a demográfiai adatokra kérdez rá, az 5-7. kérdés a tanító tapasztalataira és körülményeire, a 8-11. kérdés a játékok megjelenésére a saját tanítási szokásaikban, mikor és mely órákon jellemzőek, a 12-14. kérdések a játékok hatásaira vonatkoznak. A 15-16. kérdés a játékok funkcióira s a pedagógusok játékhasználatának céljaira, valamint a 17-19. kérdés a felhasznált játékok csoportjaira és a folyamatban alkalmazott konkrét játékokra tér ki. A kérdőívben strukturáltan, széles körü kérdésköröket alkalmazva kívántam válaszokat kapni.

A kérdőívben a zárt végű válaszok vannak túlnyomó többségben, ezen belül is a feleletválasztós vagy több válasz megjelölését engedő kérdések, illetve az értékelési skálán jelölhető válaszok, valamint a sorrendfelállítás jelenik meg. A kérdőív utolsó két kérdése nyílt végü kérdés, melynek célja, hogy egy tág képet kapjak azon konkrét játékokról, melyeket a tanítók a gyakorlatuk során rendszeresen alkalmaznak. Valamint arra is rákérdeztem, hogy szerintük melyek azok a játékok, amelyeket a leginkább kedvelnek a tanulók.

A kutatáshoz a következő hipotéziseket állítottam fel:

1. A megkérdezett tanítók több mint a fele minden nap alkalmaz játékot.

2. Az óra menetében jellemzően az óra elején (ráhangolódás) használják a legtöbb játékot a pedagógusok, és a játék egyik fő funkciójának a motivációt tekintik.

3. A pályán lévő tanítók a testnevelés és matematika tantárgyak tanításakor használnak játékokat a tanórán legnagyobb arányban.

4. A gyakorlatban a tanítók az anyanyelvi, a matematikai és mozgásos játékokat alkalmazzák jellemzően.

5. A játékok alkalmazásában a tanítókat a külső körülmények jobban gátolják, mint a diákok és a tanító motivációi. 
A kutatás főbb eredményeit fogom bemutatni a következőkben. Kiderült, hogy a legtöbb játékos tevékenység a tanórákon jelenik meg, és nem a tanórák utáni egyéb foglalkozásokon. Emellett az egyik kérdésben megkérdeztem, hogy milyen funkciókat társítanak a játékokhoz a válaszadók. Több lehetőséget is megjelölhettek. Legnagyobb arányban, a válaszadók több mint 90\%-a a motivációt és 89\%-a a gyakorló funkciót jelölte meg. De az ábrán (1. ábra) jól látható, hogy sok más funkciót is nagyra értékeltek, mint a fejlesztő, jutalom-vagy rávezető funkciók. A legkevesebben az értékelő funkciót társították a játékhoz.

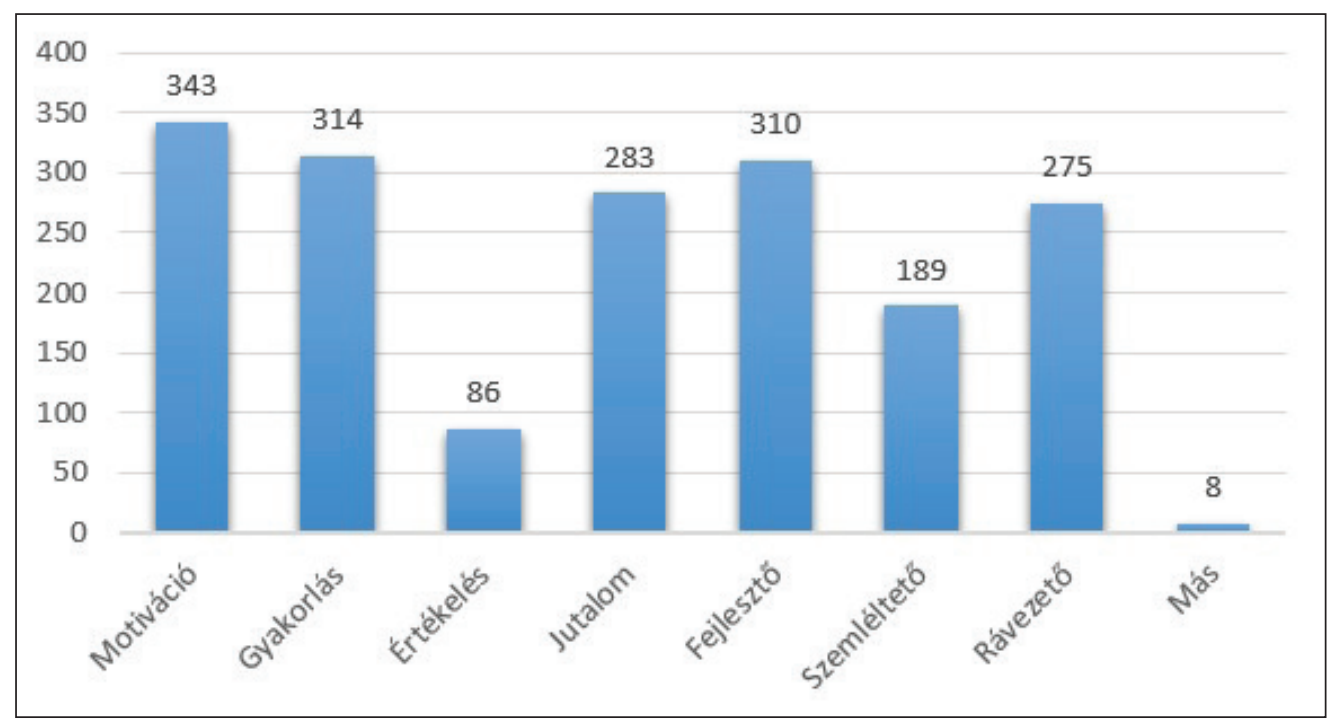

1. ábra: A játékok lehetséges funkciói a megkérdezett tanítók szerint

Fontos eredmény még, hogy a válaszok alapján nagyon is népszerủ a játékhasználat a tanítók körében, ugyanis a megkérdezettek 72\%-a minden nap alkalmaz valamilyen játékot az oktatási folyamatban. Az is fontos, hogy a tanítók fő motivációja, hogy érdekessé tegyék a tanulók számára a tanórákat. Ez arra enged következtetni, hogy a tanítók figyelembe veszik az életkori sajátosságokat, és a tanulók köré építik az órákat. Látható, hogy legnagyobb számban azt a hatást figyelték meg a válaszadók, hogy érdekesebb, izgalmasabb lesz a tanóra, ha játékos tevékenységeket alkalmaznak, valamint a tanulók is jobban figyelnek ezek hatására, és könnyebben is értik meg a tananyagot. (1. táblázat) 


\begin{tabular}{|l|l|l|}
\hline \multicolumn{1}{|c|}{ Választható állítások } & \multicolumn{1}{|c|}{ Válaszok } & \multicolumn{1}{|c|}{$\begin{array}{c}\text { Százalékos } \\
\text { arány }\end{array}$} \\
\hline Nincs pozitív hatása. & 1 & $0,3 \%$ \\
\hline Segít gyakorlatiasabbá tenni az órát. & 110 & $31,7 \%$ \\
\hline Érdekesebb, izgalmasabb a gyerekek számára. & 327 & $94,2 \%$ \\
\hline Segíti a könnyebb megértést. & 219 & $63,1 \%$ \\
\hline A gyerekek jobban figyelnek az órán. & 222 & $64 \%$ \\
\hline A gyerekek fegyelmezetlenebbek a játék hatására. & 47 & $13,5 \%$ \\
\hline Segít a fegyelmezésben. & 45 & $13 \%$ \\
\hline Egyéb & 16 & $4,6 \%$ \\
\hline
\end{tabular}

2. táblázat: Milyen hatásai lehetnek a játékoknak a tanórán?

A tantárgyak tekintetében a legtöbb játék testnevelésórán jelenik meg (2. ábra), illetve matematikaórákon. A legkevésbé az írásórákon (3. ábra) alkalmaznak játékot a megkérdezettek. Ez valószínúleg annak köszönhető, hogy a testnevelés minden nap szerepel az órarendekben, így több idő marad játékra is, sőt a játék ennél a tantárgynál egészen hangsúlyos szerepet kap a tanmenetekben is. Ezzel szemben írásórán egy kevésbé rugalmas algoritmus alapján kell magabiztos írástudást átadni a tanulóknak, kevesebb óraszámban. Emellett a múvészeti órák tekintetében leginkább az énekórán használnak játékot a tanítók, a legkevésbé pedig a rajz és technika tantárgyaknál. Ez az eredmény alátámasztja a játékgyűjtemények ajánlásait is.

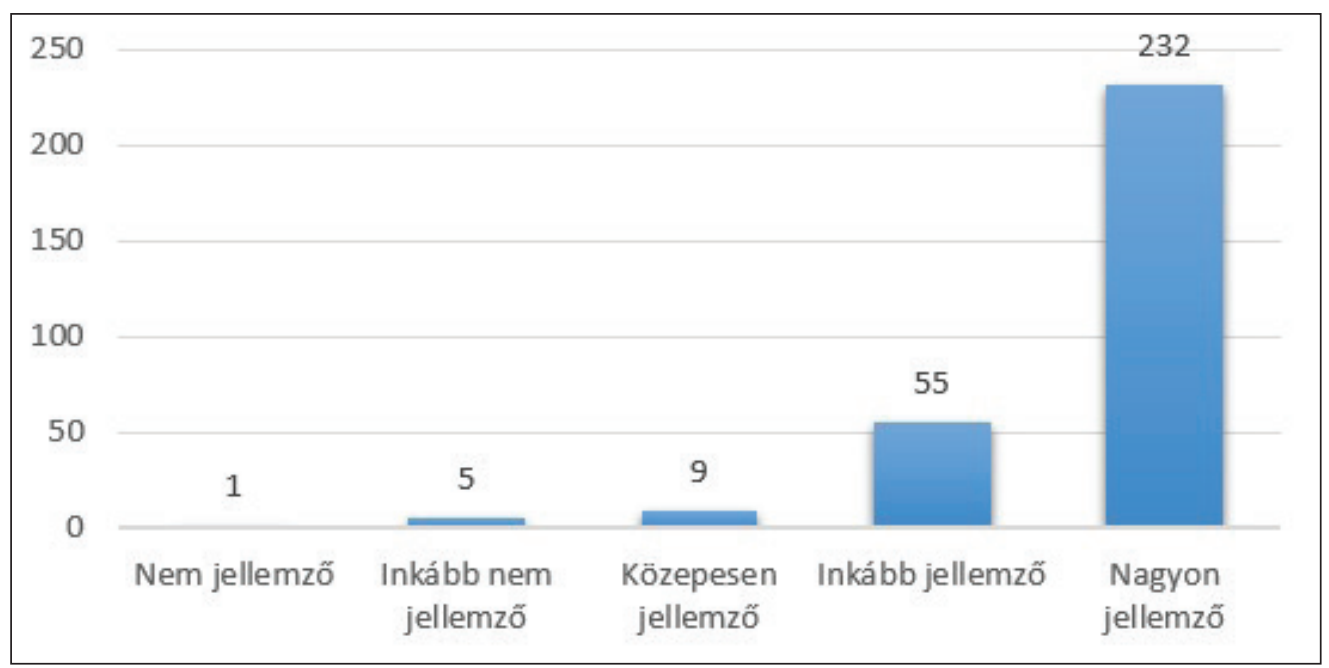

2. ábra: Játékok használatának gyakorisága testnevelés tantárgynál 


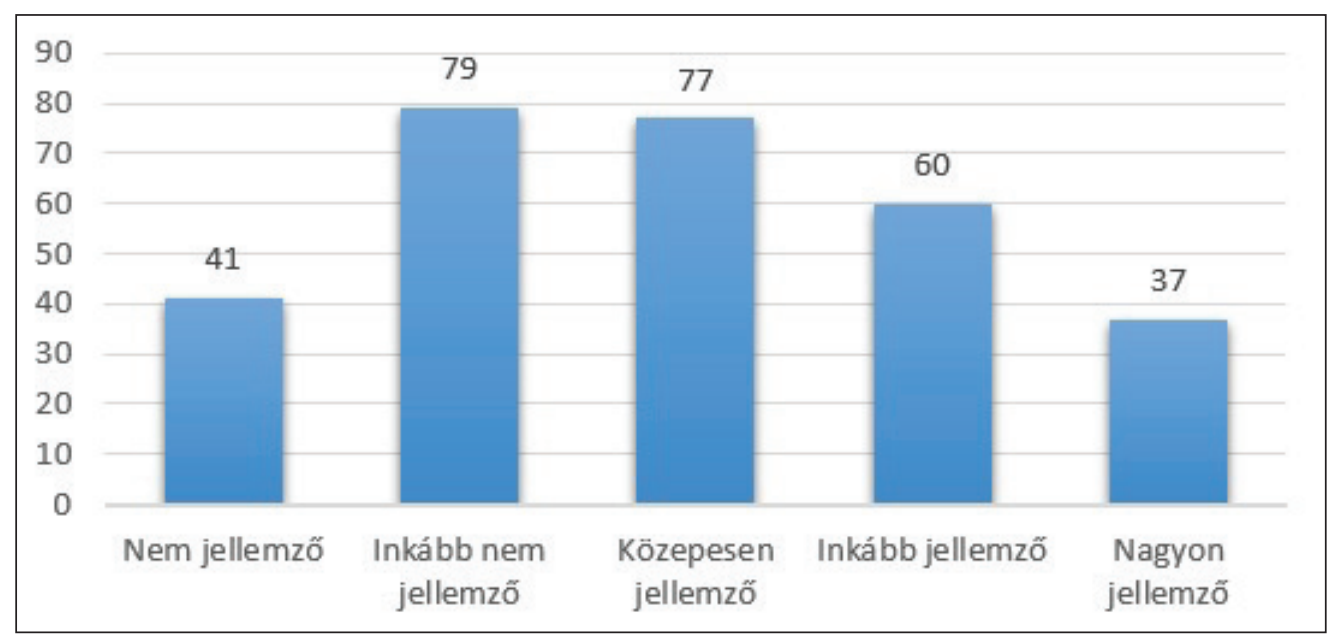

3. ábra: Játékok használatának gyakorisága írás tantárgynál

Megvizsgáltam, hogy milyen külső és egyéb akadályokba ütköznek a tanítók a játékok tervezésekor (2. táblázat). Külső akadályként olyan dolgokra gondolok, amelyek nem a pedagóguson múlnak, nem az ő szemléletüket tükrözik, hanem mint tény, megváltoztathatatlan akadály találkoznak ezekkel. Legnagyobb akadályként a tanterem méreteit jelölték meg, ezzel utalva arra, hogy kevés a hely a játékok megvalósításához, de nagy számban vannak azok, akiknek nem áll rendelkezésére a játékok elkészítéséhez megfelelő eszköz, anyag, de az osztálylétszám is befolyásoló tényező.

Ami inkább a tanítók belső akadályaiként mutatkozik meg, az például, hogy nem találnak megfelelő, az óra témájához illeszkedő játékokat, vagy úgy gondolják, nem minden óratípushoz illeszkedik a játékos tevékenység módszere.

\begin{tabular}{|l|l|l|}
\hline Választható állítások & Válaszok & Százalékos arány \\
\hline A játékeszközök elkészítése időigényes. & 183 & $52,9 \%$ \\
\hline $\begin{array}{l}\text { A játékeszközök elkészítéséhez nem áll rendelke- } \\
\text { zésre anyag (színes papír, hurkapálca stb.). }\end{array}$ & 80 & $23,1 \%$ \\
\hline A tanmenet nem teszi lehetővé. & 47 & $13,6 \%$ \\
\hline Az osztálylétszám túl magas. & 84 & $24,3 \%$ \\
\hline $\begin{array}{l}\text { A tanteremben kevés a hely a játékos tevéke- } \\
\text { nységre. }\end{array}$ & 200 & $57,8 \%$ \\
\hline A gyermekek fegyelmezetlensége. & 42 & $12,1 \%$ \\
\hline Az iskolának nincs tornaterme. & 13 & $3,8 \%$ \\
\hline Az iskolának kicsi az udvara. & 13 & $3,8 \%$ \\
\hline Egyéb & 14 & $4 \%$ \\
\hline
\end{tabular}

2. táblázat: Külső akadályok a játékok tervezésében 
Fontos eredmény még a játékkategóriák rangsorolásának alakulása. A játékkategóriák sorrendbe helyezésénél 8 opciót láthattak a tanítók, ennek kialakításában a szabályjátékok kategóriarendszerét vettem alapul (Kovács-Bakosi, 2007). A válaszadók létrehozhatták a saját gyakorlatuk szerint, hogy melyik a leginkább és a legkevésbé használt csoport a játékok tekintetében. A legtöbben az anyanyelvi játékokat tették az első helyre, és a matematikai játékokat jelölték meg másodikként, harmadik helyen pedig a mozgásos/sportjátékok végeztek. Ez alátámasztja a tantárgybontásból származó adatokat, miszerint a tanítók leggyakrabban a magyar nyelv és irodalom, matematika és testnevelés tantárgyak óráin alkalmaznak játékot. Ezek után következnek az IKT-játékok, a szociális magatartást erősítők, a vizuális, majd a dráma- és zenei játékok. Meglepőnek tartom, hogy a drámajátékok ennyire hátul végeztek a rangsorban, hiszen ez az egyik legjobban alkalmazható és variálható játéktípus.

A következőkben a hipotézisek teljesüléséről beszélek. Elmondható, hogy minden hipotézis teljesült.

1. Az első hipotézisem szerint a megkérdezett tanítók több mint fele minden nap alkalmaz játékos tevékenységet a tanórán. Ez az állítás teljesült, hiszen a kutatási eredményekből kiderült, hogy a válaszadók 72\%-a minden nap alkalmaz játékokat. Ez jóval magasabb szám, mint amit a hipotézis megfogalmazott.

2. A második hipotézis feltételezte, hogy a megkérdezett tanítók legfőképpen az óra elején, tehát a ráhangolódás részben alkalmaznak játékot, és a fő funkciónak a motivációt tekintik. Ez az állítás is teljesült. A megkérdezettek 78,7\%-a a ráhangolódó részben használ játékot, és a válaszadók 98,8\%-os arányban értékelték a motivációt meghatározó funkcióként, de arra a kérdésre, hogy a saját gyakorlatukban milyen céllal alkalmazzák a játékot, szintén erre érkezett a legtöbb válasz, $40,3 \%$.

3. A harmadik hipotézis szerint a testnevelés, valamint a matematika tantárgynál alkalmazzák a legtöbb játékot a megkérdezett tanítók. Ez az állítás is beigazolódott. Testnevelésből 76,8\% használ jellemzően játékot, s 18,2\% inkább jellemzőnek tartja a játékhasználatot. A tantárgyat illetően fontos tény még, hogy a mindennapos testnevelés bevezetésével több idő is áll a rendelkezésre akár játékok tekintetében is. Matematika tantárgyból 34,4\% inkább jellemzőnek, 45,6\% nagyon jellemzőnek tartja a játékok használatát. A többi tantárgyhoz képest ezeken a műveltségterületeken a legjellemzőbb a játékhasználat.

4. A negyedik hipotézis úgy vélte, hogy a megkérdezett tanítók jellemzően anyanyelvi, matematikai és mozgásos játékokat alkalmaznak. Akárcsak az előző hipotézisnél itt is alátámasztható az állítás. A rangsor alapján beigazolódott a hipotézis, hiszen az első három helyen valóban ezek a kategóriák végeztek, s a tantárgybontások is ezt a képet mutatták. A játékkategóriák között első helyen végzett az anyanyelvi típusú játékok 
csoportja, ezt első helyen 33,1\% (115 fő) választotta, második helyen pedig 15\% (52 fö). A matematikai csoport lett a második a rangsor szerint, 17\% (59 fő) választotta első helyen, második helyen pedig 20,7\% (72 fö).

5. Az utolsó hipotézis szerint a játékok alkalmazásában a tanítókat a külső körülmények jobban gátolják, mint a diákok és a tanító motivációi. Ez az állítás is beigazolódott, hiszen az erre irányuló két kérdésben a tanítók sokkal inkább azokat a válaszokat jelölték meg, amelyeket nem tudnak befolyásolni: a tanterem méretei 57,8\%-ot, az, hogy időigényesnek tartják elkészíteni a játékeszközöket 52,9\%-ot, az osztálylétszám 24,3\%-ot, az eszközök hiánya 23,1\%-ot ért el a válaszadási arányban. Arra a válaszlehetőségre, hogy azért nem tervez játékot, mert szerinte a tanulói nem igénylik, mindössze a megkérdezettek 4,3\%-a kattintott, $\mathrm{s}$ arra, hogy nem érzik szükségesnek a játékok alkalmazását, csupán a válaszadók 2,6\%-a. Tehát elmondható, hogy a külső tényezők sokkal inkább játszanak szerepet a játékok tervezésében és végrehajtásában.

Vizsgálatom arra irányult, hogy feltárja a játékok és játéktevékenységek alkalmazását a pályán lévő alsó tagozatos tanítók körében. Kíváncsi voltam, milyen mintázatok, tendenciák rajzolódnak ki a játékhasználat tekintetében. $\mathrm{A}$ vizsgálati mintát 347 fő tanító alkotta, az adatgyưjtést online önkitöltős kérdőív segítségével valósítottam meg, melyben hat kérdéskörhöz illeszkedve 19 kérdést fogalmaztam meg a témával kapcsolatban.

A kutatás legfontosabb eredményének azt tartom, hogy a válaszadók 72\%-a mindennap alkalmaz játékos tevékenységeket a tanórán, leginkább anyanyelvi, mozgásos és matematikai játékokat.

A téma további kutatása során több lehetséges kapcsolódó kutatási irány is kirajzolódik. Érdekes kérdésként merül fel, hogy a kerettanterv óraszámai milyen arányban vannak a játékok felhasználásával, mutatkozik-e valamilyen összefüggés ennek tekintetében. További lehetséges vizsgálati fókuszt jelenthet a készségtárgyak esetén alkalmazott játékok kvantitatív és kvalitatív vizsgálata. Újabb lehetőséget hordoz magában az általános iskolai tankönyvek elemzése, azaz mennyire játékosak az egyes múveltségi területekhez tartozó tankönyvekben lévő feladatok, mekkora teret adnak a játékok használatára a tanítási folyamatban. Leendő tanítóként úgy gondolom, a leghasznosabb egy minden pedagógus számára elérhető és az ő tapasztalataikon alapuló átfogó játékgyűjtemény elkészítése lenne. 


\section{Irodalom}

51/2012. (XII. 21.) számú EMMI rendelet mellékletei: 2012-es NAT-hoz illeszkedő kerettantervek https://net.jogtar.hu/jogszabaly?docid=A1200051. EMM\&timeshift $=20180831 \&$ txtreferer=A1400017.EMM

Bartha Árpád (1994): A játék. Budapest, Tárogató Kiadó.

Besnyi Szabolcs, Urbán Mónika (2017): Játék az osztályban! Budapest, Katalizátor Pedagógusképző Központ Bt.

Farkas Bertalan Péter (2015): IKT eszközök és módszerek a földrajtanításban http://geogo.elte.hu/images/ikt-a-foldrajztanitasban-farkas-bertalan-peter. pdf (utolsó letöltés dátuma: 2020. 05. 10.)

Horváth Zoltán (1994): 99 játék mindenkinek. Szombathely, Berzsenyi Dániel Tanárképző Főiskola.

Kerettanterv az általános iskola 1-4. évfolyamára https://kerettanterv.oh.gov. hu/01_melleklet_1-4/index_alt_isk_also.html (utolsó letöltés dátuma: 2020. 05. 10.)

Kovács György, Bakosi Éva (2007): Játékpedagógiai ismeretek. Debrecen, CenterPrint Kft.

Lewer, J.: Sex differences in the comlexity of childrens play and games American Sociological Review 43, 471-483. In: M.-R. Cole (1997): Fejlődéslélektan. Budapest, Osiris Kiadó

Maszler Irén (2002): Játékpedagógia. Pécs,Comenius Kiadó.

Mérei Ferenc, Binét Ágnes (1978): Gyermeklélektan. IV. kiadás Budapest, Gondolat Kiadó.

Millar, Susanna (1973): Játékpszichológia. Budapest, Közgazdasági és Jogi Könyvkiadó

Németh György (1994): Ókori játékok könyve. Budapest, Pesti Szalon.

Pukánszky Béla, Németh András (1996): Neveléstörténet. Budapest, Nemzeti Tankönyvkiadó Rt.

Pukánszky Béla (2002): A gyermekkor története. Pedagógus könyvek. Budapest, Műszaki Kiadó.

Sapszon Borbála (2013): Játék a zenével. Budapest, Bethlen Gábor Alapkezelő Zrt.

Sárosdi Virág (2020): Mire jó a lapbook? https://skillo.hu/mire-jo-a-lapbook/ (utolsó letöltés dátuma: 2020. 05. 10.)

Szautner Jánosné Szigeti Gizella (2017): Tanulásmódszertan tanítóknak. Szolnok, Marketing Mühely Kft. 
Újbudai Almamater Általános Iskola, Alapfokú Művészetoktatási Intézmény (2009): Játékgyüjtemény http://ujalma.hu/wp-content/uploads/2012/01/ jatekgyujtemeny_tanaroknak.pdf (utolsó letöltés dátuma 2020. 05. 10.) 